\title{
Immune Checkpoint Modulator
}

National Cancer Institute

\section{Source}

National Cancer Institute. Immune Checkpoint Modulator. NCI Thesaurus. Code

C141144.

Any agent that modulates the immune checkpoint pathway, either by blocking any inhibitory immune checkpoint protein or by activating any stimulatory immune checkpoint protein. 